\title{
ŚW. MARCIN Z TOURS - AKTUALNY MODEL MIŁOŚCI
}

Praktyczny materializm i konsumizm stawiają pod znakiem zapytania nawet najbardziej podstawowe wartości ludzkie, a wśród nich również miłość. Nasuwa się spontanicznie pytanie, czy może to właśnie o tych czasach mówił Pan Jezus w Ewangelii w słowach: „Powstanie wielu fałszywych proroków i wielu w błąd wprowadzą; a ponieważ wzmoże się nieprawość, oziębnie miłość wielu" (Mt 24, 11-12)? Jakże aktualne wydaje się być dzisiaj to dramatyczne wołanie św. Franciszka z Asyżu, który w swoich - także dość egoistycznych i mało ewangelicznych czasach - przemierzał drogi Europy wołając: „Ludzie, miłość nie jest kochana!”.

Jakby w odpowiedzi na tę niebezpieczną i tak bardzo rozpowszechnioną dzisiaj cywilizację hedonizmu i obojętności wobec innych, papież Benedykt XVI jako swój pierwszy ważny dokument ogłosił właśnie encyklikę o miłości: Deus caritas est. Pod koniec swoich rozważań Ojciec Święty nawiązuje do Świętych jako autentycznych świadków prawdziwej miłości, wyrażanej w konkretnym postępowaniu. Wśród nich szczególne miejsce przyznaje św. Marcinowi z Tours, o którym tak pisze:

„Spójrzmy na koniec na świętych, na tych, którzy w przykładny sposób wypełniali dzieło caritas. Myśl biegnie zwłaszcza ku Marcinowi z Tours († 397), najpierw żołnierzowi, a potem mnichowi i biskupowi: niczym ikona pokazuje niezastąpioną wartość osobistego świadectwa miłości. U bram Amiens, Marcin dzieli się połową swojego płaszcza z ubogim: sam Jezus ukazuje mu się w nocy we śnie ubrany w ten płaszcz, aby potwierdzić wieczne znaczenie ewangelicznego słowa: «Byłem nagi, a przyodzialiście Mnie [...]. Wszystko, co uczyniliście jednemu z tych braci moich najmniejszych, Mnieście uczynili» (Mt 25, 36. 40)"1.

Nie przypadkiem Papież przypomniał właśnie ten przykład uczynku miłości. Nie wdając się w dyskusję odnośnie szczegółów historyczno-interpretacyjnych tego wydarzenia, trzeba sobie uświadomić, iż ten rzymski żołnierz na

${ }^{1}$ Encyclica „Deus caritas est” 40, thum. pol. : Encyklika Ojca Świętego Benedykta XVI „Deus caritas est", Kraków 2006, 75, por. Sulpicius Severus, Vita sancti Martini 3, 1-3, SCh 133, 256-258. 
koniu, dający połowę swego płaszcza ubogiemu, był przez całe średniowiecze i późniejsze dzieje Europy inspiracją dla wszystkich tych, którzy mieli serca wrażliwe na potrzebujących, i stał się jakby symbolem dla całej chrześcijańskiej caritas - czynnej miłości bliźniego.

Także dzisiaj w postawie Marcina znajdujemy różne bardzo aktualne elementy. Dlatego nie tylko pod wpływem ostatniej encykliki papieskiej, ale już dużo wcześniej dostrzegało się rosnące zainteresowanie tym świętym. Jakie są przyczyny tego zjawiska? Może to właśnie z powodu tych czasów, nacechowanych chciwym egoizmem i zimną obojętnością wobec ludzkiej biedy, których źródłem są fałszywe i zwodnicze idee kapitalizmu? A może dlatego, iż w Marcinie wyraźnie widać to, co wielu intuicyjnie czuje, że droga do Boga prowadzi przez konkretne czyny miłości bliźniego? - Dalsze refleksje na temat różnych rodzajów miłości przejawiających się wyraźnie w życiu św. Marcina będą skromną próbą odpowiedzi na te pytania.

1. Miłość zwyczajna - służebna. Do wielkości dojrzewa się powoli, w ukryciu. Można śmiało powiedzieć, że także św. Marcin od dzieciństwa w ten sposób dojrzewał, chociaż prawie nic o tym nie wiemy. Pierwsze informacje, pochodzące z okresu jego służby wojskowej, mówią właśnie o jego skromności i stałej gotowości do służenia. Jako oficer miał prawo do niewolnika, aby mu usługiwał, ,któremu wszakże - zamieniwszy się rolami - jego pan służył, i to do tego stopnia, że często mu osobiście ściągał i czyścił buty. Posiłki spożywali razem, Marcin jednak częściej usługiwał" ". Postawa taka nie ograniczała się wcale do jednej osoby. Będąc pogańskim żołnierzem, Marcin już w swoim środowisku jaśniał cnotami:

„Jego wielka dobroć wobec towarzyszy, zadziwiająca miłość, cierpliwość i pokora były ponad ludzką miarę. Jego umiarkowania zaś nie trzeba nawet chwalić, gdyż postępował tak, że już wówczas był uważany nie za żołnierza, lecz za mnicha. Dzięki tym zaletom tak bardzo pozyskał sobie wszystkich współtowarzyszy, że czcili go i darzyli nadzwyczajną sympatią"”.

Biograf wylicza też konkretne działania, w których przejawiała się ta miłość:

„Posługiwał chorym, niósł pomoc biednym, wspierał potrzebujących, przyodziewał nagich. Sobie z żołdu wojskowego nie zatrzymywał nic oprócz codziennego wiktu” ${ }^{\text {. }}$.

Nie powinno nikogo dziwić, że poganin był tak dobry. Dobroć przecież nie jest zarezerwowana tylko dla ludzi wierzących. Przez wieki nie brak na to dowo-

${ }^{2}$ Sulpicius Severus, Vita Sancti Martini 2, 5, ed. J. Fontaine, SCh 133, Paris 1967, 254-256, thum. P.J. Nowak : Pisma o św. Marcinie z Tours, ŹM 8, Kraków 1995, 54.

3 Tamże 2, 7, SCh 133, 256, ŹM 8, 54.

4 Tamże 2, 8, SCh 133, 256, ŹM 8, 54. 
dów, czy to wśród mądrych filozofów i pisarzy, czy też w tysiącach przykładów dobroci u ludzi nie znających Boga, biednych i bogatych.

2. Miłość odważna - współcierpiąca. Ta jego miłość sprawiała, że wzruszał się na widok każdego potrzebującego i cierpiącego człowieka, i zaraz pragnął przyjść mu z pomocą w jego potrzebach. Jakby symbolem tego było wspomniane wydarzenie u bram Amiens, które miało miejsce jeszcze przed jego chrztem. Ale przecież był to zaledwie początek! Potem następowały liczne dalsze działania tego Świętego na rzecz cierpiących, ubogich, uciskanych, prześladowanych.

Przy okazji okrycia biedaka w Amiens połową płaszcza Marcin doświadczył od razu (i z pewnością nie po raz pierwszy), że miłość łączy się z cierpieniem. Bo z jednej strony dając biednemu połowę płaszcza, sam naraził się na skutki panującego mrozu; a z drugiej strony (jak często bywa w podobnych sytuacjach) znaleźli się też ludzie, którzy mieli go za głupca i szyderczo wyśmiewali ${ }^{5}$. Bardzo znaczące jest tu opowiadanie o tym, jak biskup Marcin, podczas gdy przygotowywał się do odprawienia uroczystej Mszy świętej w katedrze, miał w zakrystii niespodziewane odwiedziny jakiegoś biedaka, który prosił go o ubranie. Ponieważ wyznaczony do tego diakon zwlekał z wypełnieniem swego zadania, Święty za szafą dyskretnie zdjął to, co miał na sobie - pozostając okryty tylko szatami liturgicznymi - i dał biedakowi swoje ubranie. Potem diakonowi, który go przynaglał, aby już wyszedł do ołtarza i rozpoczął Mszę św., odpowiedział: „Trzeba najpierw ubrać ubogiego"6.

Wielka wrażliwość Marcina na ludzką nędzę i cierpienie ujawnia się, choć w sposób bardzo dyskretny, także przy wielu innych wydarzeniach w jego życiu. Nie było to jednak tylko płytkie współczucie, nie mające żadnego pokrycia w czynach, lecz autentyczna, odważna i konsekwentna miłość bliźniego, gotowa na każde ryzyko i na każdą ofiarę. Chyba najlepiej widać tę nieustraszoną postawę przy jego interwencjach w sprawie przeznaczonych na śmierć jeńców u komesa Awicjana, który powszechnie słynął z okrucieństwa ${ }^{7}$.

Zresztą, tak samo ryzykowne było wstawianie się za skazańcami u cesarzy, jak to pokazały fakty. Gdy Marcin wybrał się do okrutnego i pysznego Walentyniana I, ten rozkazał, aby biskupa nie wpuszczano do pałacu. Dopiero Boża interwencja, uzyskana przez modlitwę i pokutę Marcina, otworzyła mu dostęp do cesarza i jego życzliwość ${ }^{8}$. Udając się zaś do Maksyma, obwołanego cesarzem przez żołnierzy, nasz Święty chciał, aby uwolniono zamkniętych w więzieniu, odwołano skazanych na wygnanie i zwrócono im zabrane dobra. Jednak

${ }^{5}$ Por. tamże 3, 2, SCh 133, 256, ŹM 8, 55.

${ }^{6}$ Por. Sulpicius Severus, Dialogi II 1, 6, ed. C. Halm, CSEL 1, Wien 1866, 181, tłum. P.J Nowak, ŹM 8, 146.

${ }^{7}$ Por. tamże III 4, 1-7, CSEL 1, 201-202, ŹM 8, 170-171.

${ }^{8}$ Por. tamże II 5, 5-10, CSEL 1, 186-187, ŹM 8, 152-153. 
cena była wysoka: musiał odstąpić od surowości swoich zasad ${ }^{9}$. Cesarz bardzo często zapraszał biskupa do pałacu na uczty, gdzie cesarzowa słuchała z zapartym tchem słów Marcina. Nie mogła oderwać się od stóp Marcina, klęcząc przed nim na ziemi. W końcu prosiła męża, aby oboje wymogli na Marcinie, po odesłaniu całej służby, by pozwolił jej zostać samej z nim, i by mogła ona osobiście przygotować mu posiłek. Błogosławiony mąż, którego nigdy nie dotknęła żadna kobieta, nie mógł się temu sprzeciwić ${ }^{10}$.

Kiedy Marcin udał się do Trewiru, żeby się wstawić za Pryscylianem i jego stronnikami, skazanymi na śmierć, znalazł się w gorszym niebezpieczeństwie. Otóż pod wpływem wielu biskupów zebranych na dworze ze stronnictwa Itacjusza, cesarz zażądał, aby Marcin nawiązał wspólnotę z tymi biskupami, jeżeli chce ułaskawienia skazanych na śmierć. Kiedy Marcin o tym się dowiedział, pośpieszył nocą do pałacu. Uroczyście przyrzekł, że jeśli cesarz ułaskawi skazanych, to on jest gotów nawiązać wspólnotę z biskupami, byleby tylko zostali również powstrzymani trybuni, wysłani już do Hiszpanii celem zniszczenia tamtejszych kościołów. Bez zwłoki Maksym zgodził się na wszystko. Następnego dnia Marcin nawiązał wspólnotę z biskupami podczas konsekracji biskupiej Feliksa, który po depozycji Itacjusza stał się przywódcą tego stronnictwa. Uznał bowiem, że lepiej ustąpić na godzinę, aby pomóc tym, nad których głową wisiał miecz. Jednak już w drodze powrotnej odczuwał wielkie wyrzuty sumienia i został surowo napomniany przez anioła, wskutek czego potem aż do końca życia trzymał się z dala od wszystkich zebrań biskupów ${ }^{11}$.

3. Miłość apostolska - duszpasterska. W biografii Marcina Sulpicjusz Sewer często porównuje go do apostołów, a nawet do samego Chrystusa. Bez podejmowania dyskusji na temat przesadności tych porównań możemy spokojnie stwierdzić, że same fakty potwierdziły ogrom dzieła dokonanego przez św. Marcina. Jak za życia Marcina wymownym faktem była rzesza jego uczniów i innych wiernych, tak po jego śmierci przez wieki kult tego Świętego zataczał szerokie kręgi na całym świecie. Wzywali i czcili go niezliczeni biedacy, ludzie chorzy, krzywdzeni i doświadczani. Wielki jest także tłum osób wysoko postawionych: władców, książąt, papieży, biskupów, artystów, intelektualistów, wodzów, polityków i innych, których pociągała ta niesamowita osobowość i którzy na różne sposoby, prywatnie i publicznie, oddawali mu hołd czy prosili go o pomoc. Śmiało można powiedzieć, iż Marcin był i jest jednym z najbardziej czczonych na całym świecie świętych. Skąd wzięło się takie powodzenie? - Nie jest to z pewnością skutek dobrze zrobionej kampanii czy reklamy, gdyż wtedy szybko by się skończyło. Na pewno postać św. Marcina dobrze odpowiada

\footnotetext{
${ }^{9}$ Por. tamże II 7, 3, CSEL 1, 188, ŹM 8, 155.

${ }^{10}$ Por tamże II 6, 3-4, CSEL 1, 187, ŹM 8, 153-154.

11 Por. tamże III 11-13, CSEL 1, 208-211, ŹM 8, 178-181.
} 
potrzebom wszystkich ludzi, bo bez wątpienia wszyscy są spragnieni tych wartości, które on pielęgnował i niósł ludziom. Pierwszą z nich jest miłość, taka konkretna i prosta. Drugą jest nadzieja, nadająca ludzkiemu życiu głęboki sens. Ta zaś wyrasta bezpośrednio z żywej wiary w Chrystusa, tej wiary, której Marcin najpierw sam mozolnie szukał, a potem - gdy już ją znalazł i się w niej umocnił - z niewiarygodną gorliwością niósł każdemu człowiekowi, jakiego tylko mógł spotkać.

Jego przekonywującym argumentem nie były słowa, lecz czyny. Cała jego ewangelizacja była mocno osadzona na modlitwie i na surowej pokucie. Kiedy napotykał jakieś trudności, intensyfikował swą modlitwę, aż otrzymywał pomoc z nieba. Można śmiało powiedzieć, iż to ogromne dzieło ewangelizacji wsi galijskiej, dokonane przez Marcina, bardziej realizowało się dzięki cudownej pomocy udzielanej mu przez Chrystusa niż dzięki jego talentom i wysiłkom krasomówczym $^{12}$. To zatem, co na pierwszy rzut oka można by oceniać jako przesadę albo nawet fanatyzm - przede wszystkim walkę za wszelką cenę, by wykorzenić wśród ludu religię pogańską, a zastępić ją chrześcijaństwem - było autentycznie żywym znakiem jego wiary w Chrystusa i jego pełnego miłości pragnienia, aby każdemu człowiekowi umożliwić osiągnięcie zbawienia.

4. Miłość ojcowska - wymagająca. Można, bez wątpienia, uznać Marcina za ojca całego życia zakonnego w Europie Zachodniej. Jeszcze bardziej był on duchowym ojcem dla tych licznych młodych ludzi, którzy pociągnięci jego ewangelicznym sposobem życia, opuszczali wszystko i przychodzili, by w jego wspólnocie prowadzić życie całkowicie poświęcone Bogu. Marcin iście z prawdziwie ojcowską miłością troszczył się o dobro swoich braci, ale też jak ojciec był dla nich wymagający. Już sam sposób życia, jaki im proponował, wymagał nie lada ascezy! Według świadectwa Sulpicjusza Sewera, już po wyborze Marcina na biskupa Tours, w pustelni w Marmoutier, położonej ok. $3 \mathrm{~km}$ od Tours w zakolu Loary:

„On sam miał celę skleconą z gałęzi, podobnie jak liczni bracia. Wielu zaś innych wyżłobiło sobie schronienia w skale stojącej nad nimi góry. Było tam prawie osiemdziesięciu uczniów ${ }^{13}$, którzy doskonalili się za przykładem błogosławionego nauczyciela. Nikt nie posiadał nic na własność, wszystko było oddawane do wspólnego użytku. Nie wolno było niczego kupować ani sprzedawać. Młodsi zajmowali się sztuką pisania, starsi natomiast poświęcali czas na modlitwę. Rzadko kto wychodził ze swojej celi, wyjąwszzy udawanie się na miejsce modlitwy. Posiłek spożywali wszyscy razem po godzinie postu [to znaczy ok. godziny 15]. Wina nikt nie używał oprócz tych, których zmuszała do tego choroba. Wielu przyodziewało się włosiem wielbłądzim: miękkie szaty uchodziły tam za przestępstwo. Jest to tym

12 Por. Vita S. Martini 13-15, SCh 133, 280-286, ŹM 8, 68-71.

1325 lat później, w chwili śmierci Świętego, było ich ok. dwa tysiące, por. tenże, Epistola 3, 18, SCh 133, 342, ŹM 8, 104. 
bardziej godne podziwu, że wielu spośród nich było szlachetnie urodzonych: ci, przez długi czas przyzwyczajeni do innych warunków, zmuszali się do takiej pokory i cierpliwości"14.

Lecz Marcin był wymagający nie tylko w życiu ascetycznym i moralnym. Ono było podstawą, aby następnie móc być posłanym do innych z misją głoszenia Dobrej Nowiny o zbawieniu. Nie przypadkiem jest on uważany za apostoła Galii. Gdy został biskupem, przynaglany miłością Chrystusa przemierzał nie tylko swoją diecezję, lecz cały kraj, niosąc wszędzie wiarę chrześcijańską. Jednak w tych ciągłych podróżach apostolskich rzadko bywał sam: zazwyczaj wszędzie towarzyszył mu bardzo liczny orszak jego uczniów ${ }^{15}$. Łatwo można sobie wyobrazić, ile to wymagało również od nich ofiar i trudu. Nieraz nie nadązali za nim i pozostawali w tyle, a chcieli mu towarzyszyć. Uczestniczyli w jego trudach, niebezpieczeństwach i radościach, a przy okazji uczyli się od niego tej pasterskiej miłości, którą Chrystus polecał swoim apostołom: „Dobry pasterz daje życie swoje za owce" (J 10, 11).

Nic więc dziwnego, że liczne wysiłki i podróże duszpasterskie Marcina, potwierdzane też nieraz cudami, już za jego życia owocowały w postaci licznych nawróceń. Jest również zrozumiałe, że wiele diecezji i wspólnot (nie mogąc mieć u siebie jego samego) pragnęło mieć jako biskupa któregoś z uczniów Marcina i o to zabiegało. I tak pełna ofiarnej miłości troska Marcina o zbawienie ludzi obejmowała coraz większe kręgi i była kontynuowana także po jego śmierci w dziele jego uczniów.

5. Miłość współczująca - do chorych. Mimo że Marcin (ze względu na niebezpieczeństwo pychy i zbyt wielkiego rozgłosu) wystrzegał się publicznego czynienia cudów, jednak w obliczu cierpienia, zwłaszcza na prośbę rodziców błagających o łaskę dla swoich dzieci, wzruszał się i nie potrafił odmówić. Tak na przykład:

„w Trewirze była pewna dziewczynka złożona straszną chorobą paraliżu, tak że już od długiego czasu nie spełniała żadnej z ludzkich potrzeb ciała; i prawie obumarła we wszystkich członkach z ledwością jeszcze oddychała. Najbliżsi stali przy niej zasmuceni, oczekując już tylko śmierci, gdy nagle oznajmiono, że Marcin przybył do tego miasta. Ojciec dziewczynki, skoro tylko się o tym dowiedział, pobiegł co tchu, aby prosić go za swoją córką. Tymczasem Marcin wszedł już do kościoła. Tam, na oczach całego ludu i w obecności wielu innych biskupów, starzec objął jego kolana i lamentując błagał: «Moja córka umiera na straszną chorobę, a okrutniejsze od śmierci jest to, że żyje tylko duch, ciało zaś jest już obumarłe. Proszę, abyś przyszedł do niej i ją pobłogosławil, ufam bowiem, że przez ciebie powróci do zdrowia». Marcin wymawiał się, ale w końcu, przymuszony przez

14 Tenże, Vita S. Martini 10, 5-8, SCh 133, 274, ŹM 8, 65-66.

15 Por. tenże, Epistola 3, 7, SCh 133, 336-338, ŹM 8, 101-102. 
otaczających biskupów, poszedł do domu dziewczynki. Ogromny tłum oczekiwał przed drzwiami ciekaw, co też uczyni sługa Boży. On najpierw modlił się tylko leżąc krzyżem, co było jego wypróbowaną bronią w tego rodzaju sytuacjach, następnie, obejrzawszy dokładnie chorą, zażądał, aby mu podano olej. Pobłogosławiwszy go, wlał w usta dziewczynki trochę świętego płynu, i natychmiast odzyskała głos. Pod wpływem kontaktu z poświęconym olejem zaczęły odżywać powoli poszczególne członki jej ciała, aż wreszcie na oczach ludu wstała i chodziła pewnym krokiem"16.

Podobnie w Chartres ,pewien ojciec rodziny przedstawił swoją dwunastoletnią córkę niemą od urodzenia, prosząc, aby błogosławiony mąż przez swoje święte zasługi rozwiązał jej język". Prośbę poparli dwaj obecni biskupi.

„Wtedy on, nie zwlekając dłużej, kazał usunąć liczny tłum ludzi stojących dokoła. Pozostawszy tylko w obecności biskupów i ojca dziewczynki, zgodnie ze swoim zwyczajem położył się krzyżem do modlitwy. Następnie pobłogosławił odrobinę oleju słowami modlitwy odmawianej przy błogosławieństwie i poświęcony w ten sposób płyn wlał do ust dziewczynki, trzymając przy tym palcami jej język. Środek świętego okazał się skuteczny: zapytał ją o imię ojca, a ona zaraz odpowiedziała. Jej ojciec słysząc to, wykrzyknął z radości, a płacząc równocześnie i obejmując kolana świętego, wyznał ku zdumieniu wszystkich, że jest to pierwsze słowo, jakie usłyszał z ust swojej córki”"17.

Przez zasługi Marcina dokonało się też uzdrowienie jeszcze innej dziewczynki. Otóż pewien wysoki urzędnik cesarski i przyjaciel Marcina,

„prefekt Arboriusz, mąż o naturze nadzwyczaj świątobliwej i wiernej, gdy jego córka była nękana bardzo dokuczliwymi atakami gorączki kwartany, przy kolejnym przypływie temperatury położył na piersi dziewczynki list Marcina, który mu przypadkiem przyniesiono, i natychmiast opuściła ją gorączka. To wywarło na Arboriuszu tak wielkie wrażenie, że natychmiast dziewczynkę poświęcił Bogu i oddał na wieczne dziewictwo [...]. I nie pozwolił, by przyoblekłszy strój dziewictwa była konsekrowana przez kogoś innego, jak tylko przez Marcina"18.

Kiedyś ,pewna kobieta cierpiąca na upływ krwi, gdy dotknęła szaty Marcina, za przykładem owej niewiasty z Ewangelii (por. Mk 5, 25-29), w tym samym momencie została uzdrowiona"19. Mocy uzdrawiającej Marcina doświadczył w swej młodości także późniejszy biskup Noli, św. Paulin. Gdy bowiem „zachorował ciężko na oczy i już pokryła mu źrenicę ciemna, gruba zaćma, Marcin dotknął jego oka pędzelkiem i uśmierzywszy wszelki ból, przywrócił mu dawne zdrowie" 20 .

\footnotetext{
16 Tenże, Vita S. Martini 16, 2-8, SCh 133, 286-288, ŹM 8, 72-73.

17 Tenże, Dialogi III 2, 3-7, CSEL 1, 200, ŹM 8, 168-169.

18 Tenże, Vita S. Martini 19, 1-2, SCh 133, 292, ŹM 8, 75.

19 Tenże, Dialogi III 9, 3, CSEL 1, 207, ŹM 8, 176.

20 Tenże, Vita S. Martini 19, 3, SCh 133, 294, ŹM 8, 75-76.
} 
6. Miłość przebaczająca - do nieprzyjaciół. Chociaż bardzo dbał o czystość nauki i obyczajów swoich uczniów, zwłaszcza kapłanów, Marcin miał świadomość ludzkiej słabości i okazywał upadającym wielką wyrozumiałość, co oczywiście nie bardzo podobało się szatanowi:

„Niektórzy z braci zaświadczali też, iż słyszeli demona gwałtownym głosem czyniącego Marcinowi zarzuty, że pewnych braci, którzy dawniej stracili łaskę chrztu wskutek różnych błędów, później, gdy się nawrócili, przyjął do klasztoru; demon zaś wyliczał występki każdego z nich. Marcin, zwalczając diabła, odpowiadał ciągle, że dawne wykroczenia zostały odpokutowane prowadzeniem lepszego życia, a tym, którzy przestaną grzeszyć, przez miłosierdzie Boże będą one odpuszczone ${ }^{" 21}$.

Wśród swoich uczniów Marcin miał czasem osoby trudne. Jedną z nich był Brykcjon. Z pochodzenia ubogi, w klasztorze żyjący ponad stan (trzymał konie i nabywał niewolników, a niektórzy zarzucali mu, że wśród nich kupował także piękne dziewczęta) - gdy Biskup go napomniał, wpadł w furię:

„Napadł na Marcina tak gwałtownie, że z trudem powstrzymano go od rękoczynów. Święty tymczasem zachował łagodne oblicze i spokój ducha, usiłując oględnymi słowami powściągnąć szaleństwo tego biedaka"22.

Marcin był świadom, że to sprawka szatana. Dlatego nie gniewał się na ubliżającą mu osobę, lecz odpowiadał modlitwą. A kiedy Brykcjon ,przepełniony skruchą wkrótce powrócił i upadł Marcinowi do kolan błagając o przebaczenie, uznając swój błąd i przyznając, że był omotany przez złego ducha, nie było trudno proszącemu uzyskać u Marcina przebaczenie"23. Ta przebaczająca miłość nie była tylko chwilowa czy zewnętrzna. Potwierdzają to fakty:

„Później, gdy wobec Marcina tego samego Brykcjona oskarżano o liczne i ciężkie przewinienia, on mimo to nie dał się nakłonić do pozbawienia go godności kapłańskiej" 24 .

Zaś już po śmierci Świętego - jakby na potwierdzenie tej postawy pełnej miłości - właśnie Brykcjon został wybrany jego następcą. Już od początku spotykał się z silną opozycją dawnych współbraci i różnymi atakami. Złożony z urzędu z powodu oszczerstw, w 331 r. udał się do Rzymu. Uniewinniony przez papieża św. Juliusza I powrócił na stolicę biskupią i umarł w opinii świętości w 344 roku. Św. Brykcjon został pochowany w Tours w kościele św. Marcina, który za życia kazał wybudować. Wkrótce po śmierci rozpowszechnił się jego

21 Tamże 22, 3-4, SCh 133, 300-302, ŹM 8, 79-80.

22 Tenże, Dialogi III 15, 2-3, CSEL 1, 213, ŹM 8, 184.

23 Tamże III 15, 5-6, CSEL 1, 214, ŹM 8, 184.

24 Tamże III 15, 7, CSEL 1, 214, ŹM 8, 184-185. 
kult. Jego wspomnienie liturgiczne przypada 13 listopada $^{25}$. Bardzo piękne jest świadectwo, jakie daje o nim pod koniec swego pierwszego dzieła (napisanego jeszcze za życia Marcina) Sulpicjusz Sewer:

„O mąż prawdziwie błogosławiony, w którym nie było podstępu, który nikogo nie sądził, nikogo nie potępiał, nikomu nie odpłacał złem za złe. Odznaczał się bardzo wielką cierpliwością wobec wszystkich doznawanych niesprawiedliwości. Chociaż był biskupem, krzywdzony bezkarnie - także przez duchownych najniższego stopnia - nigdy z tego powodu nikogo ani nie usunął z jakiegoś stanowiska, ani też, na ile to zależało od niego, nie odepchnął od swojej miłości" 26 .

7. Miłość do całego stworzenia. Pomimo ciągłego przeogromnego zaangażowania duszpasterskiego, Marcin nie dał się porwać aktywizmowi, który dziś tak często powoduje, że ludzie żyją tylko dla jakiejś idei i nie mają czasu na nic innego: ani dla najbliższych, ani dla siebie, ani też by zatrzymać się z podziwem czy współczuciem dla otaczającej nas przyrody. On żył w harmonii i bliskości z całą naturą, szczególnie jako mnich, ale także później jako biskup - wędrowny misjonarz. Miał od Boga taką moc, że „oswajał aż do granic poufałości wściekłe bestie i jadowite węże"27. Różne epizody, wspomniane przez jego biografa, uchylają nam rąbka tajemnicy jego intymnej komunii z całym Bożym stworzeniem i jego miłości do niego. Podobnie jak u ludzi, tak w świecie zwierząt Marcin współczuł zdecydowanie słabszym i tym, którym groziło niebezpieczeństwo. Nieraz też w sposób cudowny przychodził z pomocą. I tak widząc w drodze, jak podczas polowania psy ścigały zająca, który nie miał już możliwości ucieczki, „wrażliwe serce błogosławionego męża ulitowało się nad tym stworzeniem... Rozkazał psom, aby zaniechały pogoni i pozwoliły mu uciec". Na co one stanęły jak wryte, a zajączek bezpieczny uciekt ${ }^{28}$.

Już u schyłku swego życia, zmierzając do Candes, by pojednać tamtejszych duchownych, po drodze zobaczył drapieżne nurki, jak latały nad wodą i łowiły ryby. Porównując te żarłoczne ptaki do demonów, które łowią i pożerają nieostrożne dusze, kazał im odlecieć na miejsca bezwodne i pustynne, co one też natychmiast uczyniły ${ }^{29}$. Jeszcze bardziej zdumiewa historia pewnej krowy, która była tak agresywna, że stanowiła poważne zagrożenie dla wszystkich przechodzących w pobliżu. Kiedy Marcin tamtędy przechodził z uczniami, pasterze już z daleka wołali, ostrzegając ich przed niebezpieczeństwem. Lecz Marcin, wyposażony nadzwyczajnymi darami, od razu dostrzegł, iż to biedne zwierzę było dręczone przez ujeżdżającego je demona. Kiedy więc mocą Świę-

\footnotetext{
25 Por. G. Bataille, Brizio di Tours, BS III 542-545.

26 Sulpicius Severus, Vita S. Martini 26, 5, SCh 133, 314, ŹM 8, 86.

27 Tenże, Dialogi I 25, 1, CSEL 1, 177, ŹM 8, 140.

${ }^{28}$ Por. tamże II 9, 6, CSEL 1, 191, ŹM 8, 158.

29 Por. tenże, Epistola 3, 6-8, SCh 133, 336-338, ŹM 8, 101-102.
} 
tego zły duch został przepędzony, krowa łagodna jak owieczka położyła się $\mathrm{z}$ wdzięcznością u jego stóp, a następnie wróciła do swego stada ${ }^{30}$.

\section{$* * *$}

Obraz miłości św. Marcina byłby niekompletny, a nawet pozbawiony swego źródła, gdybyśmy nie wspomnieli o jego wielkiej miłości do Chrystusa. Od owego pamiętnego dnia, gdy Pan ukazał mu się we śnie - jak to pięknie ujął Sulpicjusz Sewer - ,na jego ustach nie było nigdy nic innego, jak tylko imię Chrystusa, w sercu - tylko pobożność, pokój i miłosierdzie" ${ }^{31}$.

Naprawdę ta chrystocentryczna pobożność Marcina jest uderzająca w swej głębi i prostocie, w swej mocy i skuteczności. Wydaje się, że również ta jego cecha może ukazać w naszych czasach jasne światło ludziom, którzy nieraz pod wpływem naturalnej potrzeby Boga szukają Go, ale są zdezorientowani i gubią się w ogólnym zamieszaniu. Marcin bowiem z jednej strony był dobrze obeznany z nauką Ewangelii i z całą doktryną katolicką, której bardzo stanowczo bronił jeszcze zanim został mnichem czy biskupem - do tego stopnia, iż w Mediolanie był prześladowany i wypędzony z tego powo$\mathrm{du}^{32}$. Z pewnością tę rzetelną formację zawdzięczał św. Hilaremu, który podobnie jak on przyjął wiarę katolicką już jako dorosły człowiek pod wpływem lektury Ewangelii, a potem stał się nieustraszonym jej obrońcą w całym rzymskim imperium. $\mathrm{Z}$ drugiej strony Marcin nigdy nie wdawał się w teoretyczne dyskusje, nie pisał uczonych traktatów, a jego nauki były bardzo krótkie i proste, przepojone treścią duchową, przeważnie oparte lub wzorowane na Ewangelii ${ }^{33}$.

Po długiej służbie wojskowej Marcin w wielu rzeczach zachował wojskowy sposób myślenia i działania. Można więc śmiało powiedzieć, że także w swej relacji do Chrystusa był on podobny do starego żołnierza, który kocha swego wodza. Miłość ta wyrażała się nie tyle w uczuciach czy słowach, co raczej w głębokim zaufaniu, wiernej służbie, ochoczym posłuszeństwie na każdy rozkaz i gotowości, a nawet gorącym pragnieniu, by za swoim wodzem iść do walki i oddać za niego życie.

\footnotetext{
${ }^{30}$ Por. tenże, Dialogi II 9, 1-4, CSEL 1, 190-191, ŹM 8, 157.

31 Tenże, Vita S. Martini 27, 2, SCh 133, 314, ŹM 8, 86.

${ }^{32}$ Por tamże 6, 4, SCh 133, 264-266, ŹM 8, 60.

33 Por. tenże, Dialogi II 10, 1-3, CSEL 1, 191-192, ŹM 8, 158-159.
} 


\section{SAN MARTINO DI TOURS - ATTUALE MODELLO DI CARITÀ}

(Riassunto)

Dalla prospettiva di oltre sedici secoli dalla morte di san Martino, ci si pone la domanda sul motivo di grande popolarità che lo circondava già durante la sua vita, $\mathrm{e}$ molto più dopo la morte. La risposta non può esaurirsi in una parola, perché vi sono più motivi che contribuiscono a questo fatto.

$\mathrm{Al}$ primo posto certamente bisogna riconoscere la sua personale grande carità, come ci ha ricordato recentemente il Santo Padre Benedetto XVI nell'enciclica Deus caritas est, dicendo all'inizio della conclusione (n. 40): „Guardiamo infine ai Santi, a coloro che hanno esercitato in modo esemplare la carità. Il pensiero va, in particolare, a Martino di Tours, prima soldato poi monaco e vescovo: quasi come un'icona, egli mostra il valore insostituibile della testimonianza individuale della carità".

Questa sua carità si commuove di fronte ad ogni bisognoso e sofferente, e subito si sente spinta ad agire. diventata quasi un simbolo di san Martino questa scena, avvenuta ancora prima del suo battesimo, in cui d'inverno nella città di Amiens egli taglia la metà del suo mantello per coprire un mendicante afflitto dal freddo. Ma era appena l'inizio. Poi seguirono molti altri interventi di quel Santo a favore dei sofferenti, poveri, oppressi, perseguitati. Egli non esitava per questo a recarsi anche presso i tiranni e gli imperatori. Cercava perfino di impedire la condanna a morte di Prisciliano e i suoi seguaci.

Però la sua carità non si limitava solo agli uomini, ma comprendeva perfino gli animali, come ci mostrano alcuni episodi dalla sua vita, p.e. quello della lepre salvata dai cani da caccia che la inseguivano o della vacca furiosa liberata dal demonio.

Certo, al centro della sua carità e di tutta l'attività era il bene spirituale dei fratelli. Perciò instancabilmente percorreva tutta la Gallia, anzi, possiamo dire tutta l'Europa, per portare dovunque il messaggio del Vangelo. La religione cristiana in Gallia era infatti in minoranza e limitata quasi esclusivamente alle città, mentre nella campagna dominava ancora la religione pagana. Martino era proprio convinto che l'unico Salvatore dell'uomo è Gesù Cristo. Si affrettava dunque ad annunciare Cristo e ad accogliere come catecumeni tutti coloro che credevano al suo messaggio.

San Martino non era un personaggio che si comportava come un nobile, non apparteneva alle corti imperiali o a gruppi esclusivi, ma apparteneva alla gente comune, da cui fu ben accettato e seguito con grande entusiasmo. Loro apprezzavano il suo tesoro della vita interiore con Dio e la sua carità verso il prossimo. Perciò anche dopo la sua morte, e nei secoli, egli fu considerato dai poveri ed oppressi il loro difensore e padre, a cui si rivolgevano con fiducia nei loro bisogni e pericoli. Ciò spiega anche in qualche modo la grande diffusione del suo culto in tutta l'Europa. 